\title{
Community-Associated Methicillin-Resistant Staphylococcus aureus Infective Endocarditis with Panton-Valentine Leukocidin Gene in an Injection Drug User with HIV Infection
}

\author{
Hung-Chin Tsai ${ }^{1-3}$, Pei-Jiuan Chao ${ }^{1,2}$, Cheng-Len Sy ${ }^{1,2}$, Susan Shin-Jung Lee ${ }^{1,2}$, \\ Yao-Shen Chen ${ }^{1,2}$, Shue-Ren Wann ${ }^{1,2}$ and Yung-Ching Liu ${ }^{1,2}$
}

\begin{abstract}
Reports of community-associated methicillin-resistant Staphylococcus aureus (CA-MRSA) isolates carrying Panton-Valentine leukocidin (PVL) gene that causes infective endocarditis in injection drug users (IDUs) with human immunodeficiency virus (HIV) infection are rare in the English language literature. We present a case of CA-MRSA infective endocarditis with bilateral septic lung emboli in a previously healthy 45-year-old IDU. This case suggests that PVL gene-positive CA-MRSA should be considered as a potential pathogen in IDUs with infective endocarditis.
\end{abstract}

Key words: infective endocarditis, intravenous drugs user, methicillin-resistant, Staphylococcus aureus

(Inter Med 47: 1485-1489, 2008)

(DOI: 10.2169/internalmedicine.47.0878)

\section{Introduction}

Increasing rates of methicillin-resistant Staphylococcus aureus (MRSA) globally have been accompanied by the increase of MRSA infections among healthy individuals in the community without apparent traditional risk factors (1). Community-associated methicillin-resistant Staphylococcus aureus (CA-MRSA) infections are now regarded as a serious public health problem (2). Although infective endocarditis due to CA-MRSA has been reported in a case series (3), none was reported in patients with human immunodeficiency virus (HIV) infection. Herein, we report a 45-yearold HIV-infected man with infective endocarditis caused by CA-MRSA isolates carrying Panton-Valentine leukocidin (PVL) gene. He was treated successfully with linezolid and trimethoprim/sulfamethoxazole without surgical intervention.

Case Report

This previously healthy 45-year-old injection drug user (IDU) presented to our hospital with 1 week of fever, intermittent chills, and left leg pain. He started to inject morphine sulfate intravenously 2 months prior to admission and had not been hospitalized in the past nor had any recent antibiotic usage. He was admitted to another hospital one week prior to admission because of fever, dyspnea and cough after a motor vehicle accident and blood culture revealed presence of MRSA. A transthoracic echocardiogram revealed a $2 \mathrm{~cm}$ vegetation over the tricuspid valve. He was transferred to our hospital for further evaluation after he tested positive for HIV, hepatitis B and hepatitis C.

At presentation, his temperature was $39^{\circ} \mathrm{C}$. Physical examination revealed a grade $2 / 6$ systolic murmur on the left lower sternal border. Laboratory examination showed a peripheral leukocyte count of $1.2 \times 10^{4}$ cells $/ \mathrm{mm}^{3}$ with $97 \%$ polymorphonuclear cells. Chest radiography revealed the

\footnotetext{
${ }^{1}$ Section of Infectious Diseases, Department of Medicine, Kaohsiung Veterans General Hospital, Kaohsiung, Taiwan, Republic of China, ${ }^{2}$ National Yang-Ming University, Taipei, Taiwan, Republic of China and ${ }^{3}$ Graduate Institute of Medicine, Kaohsiung Medical University, Kaohsiung, Taiwan, Republic of China

Received for publication January 3, 2008; Accepted for publication May 20, 2008

Correspondence to Dr. Yung-Ching Liu, hctsai1011@yahoo.com.tw
} 


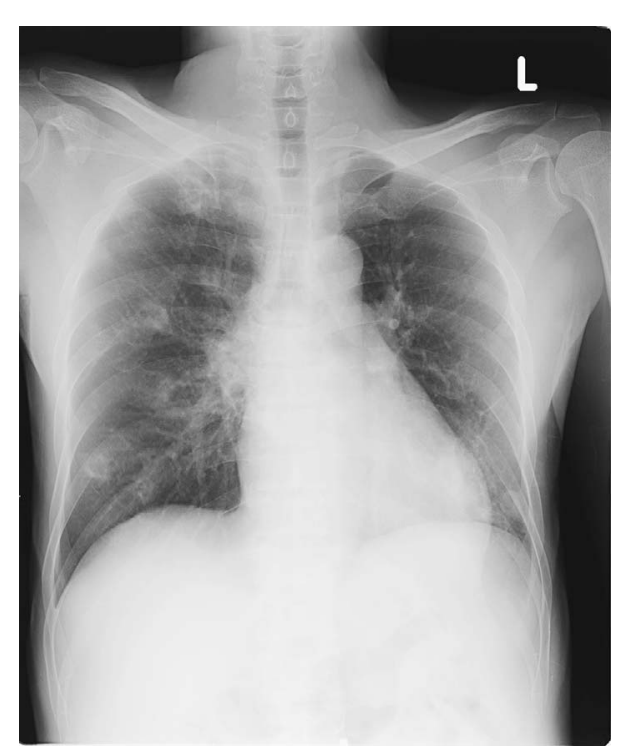

Figure 1. Chest radiography revealed the presence of bilateral septic lung emboli

presence of bilateral septic emboli (Fig. 1). Two sets of blood cultures grew MRSA within 24 hours; the blood isolate was sensitive to vancomycin, trimethoprim/sulfamethoxazole, linezolid, minocycline, levofloxacin, chloramphenicol and moxifloxacin. Screening for PantonValentine leukocidin (PVL) genes by PCR (4) was positive. The PCR product for PVL was verified by subjecting the sample to gene sequencing using ABI 310 gene analyzer based on the Sanger dideoxy nucleotide triphosphate (ddNTP) terminator method. The isolate was identified to have a type IV staphylococcal cassette chromosome mec (SCCmec) (5). His CD4 lymphocyte count was 320 cells $/ \mu \mathrm{L}$ and his HIV viral load was $>100,000$ copies/mL (Roche Amplicor 1.5). The patient initially received vancomycin and subsequently teicoplanin and rifampin and the regimen was changed to linezolid on hospital day 17 due to the appearance of skin rashes and persistence of MRSA bacteremia. A transesophageal echocardiogram at our hospital also showed a $2 \mathrm{~cm}$ vegetation that was fixed to the anterior leaflet of the tricuspid valve (Fig. 2). Mild tricuspid regurgitation was noted. Computed tomography (CT) of the chest disclosed multiple bilateral pulmonary nodules, some of which were cavitary and were suspicious of septic pulmonary emboli. Blood cultures turned negative for MRSA after $7 \mathrm{~d}$ of treatment. He received 3 weeks of linezolid and a hemogram performed one day before discharge showed no evidence of thrombocytopenia or mild anemia ( $\mathrm{HgB} 10 \mathrm{~g} / \mathrm{dL})$. However, five days after discharge, he was admitted because of fever and diarrhea. Laboratory examination showed a peripheral leukocyte count of $1.13 \times 10^{4}$ cells $/ \mathrm{mm}^{3}$ with $71 \%$ polymorphonuclear cells and $22 \%$ lymphocytes; hemoglobin of $6.5 \mathrm{~g} / \mathrm{dL}$ and platelet count of $2.1 \times 10^{5}$ cells $/ \mathrm{mm}^{3}$. Blood culture revealed MRSA with the same antibiogram. He was initially treated with teicoplain, rifampin and gentamicin for 10 days and shift to linezolid and trimethoprim/sul-

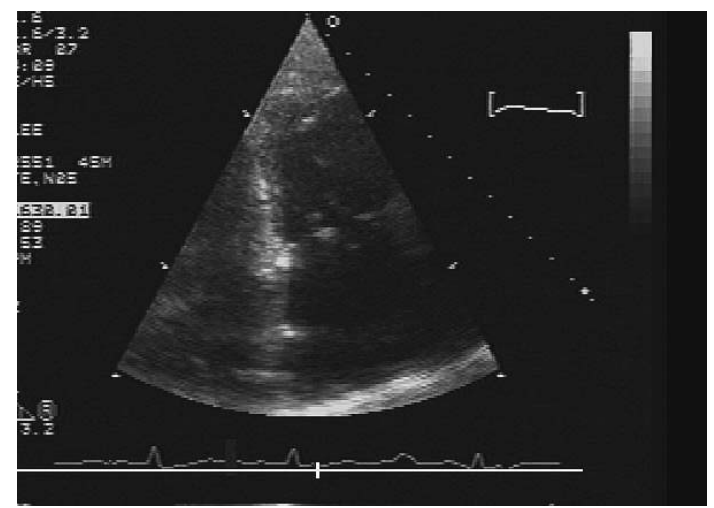

Figure 2. A transesophageal echocardiogram showed a vegetation at the anterior leaflet of the tricuspid valve ( $R V$ inflow view).

famethoxaole due to fever and relapsing MRSA bacteremia. Blood culture turned negative and fever subsided after 5 days of treatment. He was given 4 weeks of linezolid and trimethoprim/sulfamethoxazole and both were discontinued because of pancytopenia ( $\mathrm{Hgb} 8 \mathrm{~g} / \mathrm{dL}$, platelet $2.3 \times 10^{4}$ cells/ $\mathrm{mm}^{3}$, white cell count 3,800 cells $/ \mathrm{mm}^{3}$ ). The clinical course of this patient is summarized in Fig. 3. A repeated transthoracic echocardiogram showed partially healed tricuspid vegetations. He was followed up at Out Patient Department with no obvious complications.

\section{Discussion}

A Medline search of English language literature from January 1999 to July 2007 for cases with communityassociated MRSA (CA-MRSA) infective endocarditis was performed and included the following individual search terms: 'CA-MRSA', 'CO-MRSA', or 'community-acquired MRSA'. The above-mentioned terms were combined with 'endocarditis'. Inclusion criteria were: 1) communityassociated MRSA bacteremia, defined as isolate recovered within 48 hours to 72 hours of admission; 2) infective endocarditis fulfilling modified Duke criteria for definite infective endocarditis (6); 3) molecular data available on SCCmec typing, with or without data available on PVL gene testing. There were 8 previously reported cases of CAMRSA infective endocarditis in patients with IDUs that fulfilled our criteria (Table 1). All 9 patients carried the SCCmec IV gene. However, six of MRSA isolates (66\%) were PVL positive. Only the present patient had HIV infection.

A longitudinal study of 282 community-based drug abusers conducted from February 1999 through September 2000 in New York showed high rates of incident $S$. aureus colonization present in IDUs. Moreover, HIV serostatus was significantly and uniquely associated with $S$. aureus incidence and persistence and with MRSA colonization (11). No therapeutic or clinical factors of HIV infection were found to increase the risk of colonization (11). The present patient 


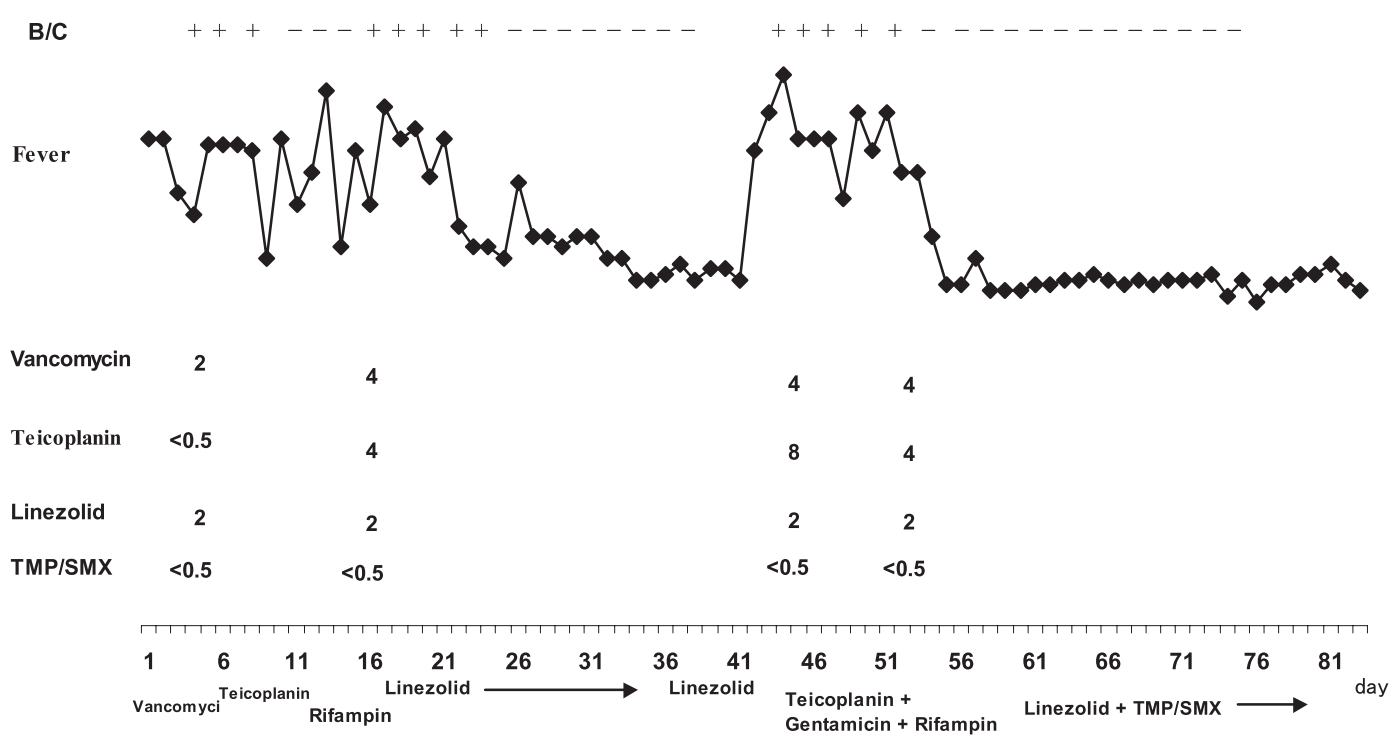

Figure 3. Clinical course and tested minimum inhibitory concentrations of the isolated strain of CA-MRSA in our patient with CA-MRSA infective endocarditis. B/C: blood culture, TMP/SMX: trimethoprim/sulfamethoxazole.

had no skin lesions to explain the source of MRSA bacteremia and endocarditis. Although we did not test $S$. aureus colonization before the patient became ill, HIV itself may have had some contribution in the $S$. aureus colonization (11).

Community-associated (CA) and health care-associated (HA) MRSA cases differ demographically and clinically (12). Community-acquired strains were characterized by limited antibiotics resistance, with cellulitis and abscess being the major clinical manifestations $(4,13)$. They have a common pulsed-gel electrophoresis (PFGE) pattern, possess different exotoxin gene profiles (e.g., PVL) and harbor type IV staphylococcal cassette chromosome mec (SCCmec) $(4,12$, 13). In contrast, health care-associated MRSA were mainly type I to III SCCmec $(12,14)$. Cases of CA-MRSA have been increasing recently (15). In Taiwan, MRSA colonized a substantial proportion of healthy children and accounted for $25 \%$ to $75 \%$ of childhood CA-MRSA infections $(15,16)$. The most common SCCmec types were type IV and $\mathrm{V}_{\mathrm{T}}$ (1517). However, in the study of Huang et al (18), they found that SCCmec type IV consisted of $43 \%$ of their hospitalassociated MRSA isolates in 2005. Another study also demonstrated that SCCmec type IV was found in $40 \%$ of their patients with hospital-associated MRSA (16). This suggests that SCCmec type IV, which is usually community associated, was closed related to hospital acquired isolates. Although the present patient had no risk factor for hospitalassociated MRSA, the possibility of clonal spread of SCCmec type IV MRSA between community and hospital can not be excluded. The combination of CA-MRSA in skin lesions and skin trauma through intravenous drug injection may represent a new susceptible population for the acquisition of CA-MRSA endocarditis such as in our patient.

The decision to operate on patients with infective endo- carditis is determined primarily on the severity of congestive heart failure. Other clinical situations in which surgical intervention should be considered are fungal infective endocarditis, infection with aggressive antibiotic-resistant bacteria or bacteria that respond poorly to antibiotics, left-sided endocarditis caused by Gram-negative bacteria such as $S$. marcescens and Pseudomonas species, persistent infection with positive blood cultures after 1 week of antibiotic therapy, or 1 or more embolic events during the first 2 weeks of antimicrobial therapy (19). Our patient refused surgical intervention because of personal economic consideration and lack of family support and his decision was respected.

This case was different from the previously reported cases. First, this is the first case with HIV coinfection. Secondly, the antibiotic susceptibility pattern in this case is different from the others. In Taiwan, the strikingly high prevalence of macrolide resistance in clinical isolates of Streptococcus pyogenes appears to be associated with the widespread medical use of these agents. This continuous and widespread utilization may have contributed to the remarkably high incidence of erythromycin and clindamycin resistance among the CA-MRSA isolates from our patient and children in this region (20).

PVL-producing S. aureus appeared to be associated with furunculosis, cutaneous abscesses, severe necrotic skin infections and severe hemorrhagic pneumonia $(4,13)$. But PVL gene is rarely found in other infections such as infective endocarditis. However, PVL gene was frequently detected in CA-MRSA $(4,13)$. In the study of Huang et al (18), PVL genes were detected in $50 \%$ of their CA-MRSA isolates. The detection of PVL gene in our CA-MRSA isolate with infective endocarditis may only reflect the high prevalence of PVL-producing $S$. aureus in Taiwan or it may be due to a clonal spread of PVL genes between community and hospi- 
Table 1. Clinical and Molecular Characteristics of Patients with CA-MRSA Infective Endocarditis in IDUs

\begin{tabular}{|c|c|c|c|c|c|c|c|}
\hline Patient & Country & $\begin{array}{l}\text { Valve } \\
\text { involved }\end{array}$ & SCCmec & PVL & Therapy & Outcome & Reference \\
\hline 1 & Taiwan & Tricuspid & Type IV & Positive & $\begin{array}{l}\text { Chloramphenicol, } \\
\text { trimethoprim/sulfamethoxazole } \\
8 \text { weeks }\end{array}$ & $\begin{array}{l}\text { Survived (no valvular } \\
\text { surgery) }\end{array}$ & Current case \\
\hline 2 & USA & Tricuspid & Type IVd & Negative & Vancomycin/ rifampin 6 weeks & $\begin{array}{l}\text { Survived } \\
\text { (TV replacement) }\end{array}$ & 7 \\
\hline 3 & Singapore & Tricuspid & Type IVa & Negative & Vancomycin 6 weeks & $\begin{array}{l}\text { Survived } \\
\text { (TV replacement) }\end{array}$ & 8 \\
\hline 4 & Australia & Tricuspid & Type IV & Not tested & Vancomycin/ rifampin 6 weeks & $\begin{array}{l}\text { Survived (no valvular } \\
\text { surgery) }\end{array}$ & 9 \\
\hline 5 & USA & Aortic & Type IV & Positive & $\begin{array}{l}\text { Vancomycin } 6 \text { weeks/gentamicin } \\
2 \text { weeks }\end{array}$ & $\begin{array}{l}\text { Died } 11 \text { months } \\
\text { following discharge } \\
\text { due to subarachnoid } \\
\text { hemorrhage and } S \text {. } \\
\text { aureus bacteremia } \\
\text { (porcine bioprosthetic } \\
\text { valve) }\end{array}$ & 10 \\
\hline 6 & USA & Tricuspid & Type IV & Positive & $\begin{array}{l}\text { Vancomycin } 6 \text { weeks/gentamicin } \\
4 \text { days }\end{array}$ & $\begin{array}{l}\text { Loss of follow up, } \\
\text { blood culture clear at } \\
\text { discharge }\end{array}$ & 10 \\
\hline 7 & USA & $\begin{array}{l}\text { Between } \\
\text { pulmonic } \\
\text { valve and } \\
\text { tricuspid } \\
\text { valve }\end{array}$ & Type IV & Positive & $\begin{array}{l}\text { Vancomycin } 6 \text { days/gentamicin } \\
6 \text { days }\end{array}$ & $\begin{array}{l}\text { Status unknown, leave } \\
\text { against medical advice }\end{array}$ & 10 \\
\hline 8 & USA & Tricuspid & Type IV & Positive & $\begin{array}{l}\text { Vancomycin } 39 \text { days/gentamicin } \\
7 \text { days, changed to daptomycin } \\
\text { due to renal failure, discharge on } \\
6 \text { weeks clindamycin }\end{array}$ & $\begin{array}{l}\text { No signs of infection } 1 \\
\text { week post-discharge } \\
\text { (no valvular surgery) }\end{array}$ & 10 \\
\hline 9 & USA & Aortic & Type IV & Positive & Vancomycin 5 weeks & $\begin{array}{l}\text { Status unknown, did } \\
\text { not return for } \\
\text { follow-up }\end{array}$ & 10 \\
\hline
\end{tabular}

SCCmec: staphylococcal cassette chromosome mec; PVL: Panton-Valentine leukocidin; CA-MRSA: community-associated methicillin-resistant Staphylococcus aureus; Therapy: final antibiotic regimen with length of treatment. TV: Tricuspid valve

tal. The clinical significance of PVL gene in IE needs further study. In conclusion, the present case suggests that PVL gene-positive CA-MRSA should be considered as a potential pathogen in IDUs with HIV infection and endocarditis.

\section{References}

1. Boyle-Vavra S, Daum RS. Community-acquired methicillinresistant Staphylococcus aureus: the role of Panton-Valentine leukocidin. Lab Invest 87: 3-9, 2007.

2. Fridkin SK, Hageman JC, Morrison M, et al. Methicillin-resistant Staphylococcus aureus disease in three communities. N Engl J Med 352: 1436-1444, 2005.

3. Millar BC, Prendergast BD, Moore JE. Community-associated MRSA (CA-MRSA): an emerging pathogen in infective endocarditis. J Antimicrob Chemother 61: 1-7, 2008.

4. Lina G, Piemont Y, Godail-Gamot F, et al. Involvement of PantonValentine leukocidin-producing Staphylococcus aureus in primary skin infections and pneumonia. Clin Infect Dis 29: 1128-1132, 1999.

5. Oliveira DC, de Lencastre H. Multiplex PCR strategy for rapid identification of structural types and variants of the mec element in methicillin-resistant Staphylococcus aureus. Antimicrob Agents Chemother 46: 2155-2161, 2002.
6. Li JS, Sexton DJ, Mick N, et al. Proposed modifications to the Duke criteria for the diagnosis of infective endocarditis. Clin Infect Dis 30: 633-638, 2000.

7. Tsigrelis C, Armstrong MD, Vlahakis NE, Batsis JA, Baddour LM. Infective endocarditis due to community-associated methicillin-resistant Staphylococcus aureus in injection drug users may be associated with Panton-Valentine leukocidin-negative strains. Scand J Infect Dis 39: 299-302, 2007.

8. Hsu LY, Koh TH, Tan TY, et al. Emergence of communityassociated methicillin-resistant Staphylococcus aureus in Singapore: a further 6 cases. Singapore Med J 47: 20-26, 2006.

9. Murray RJ, Lim TT, Pearson JC, Grubb WB, Lum GD. Community-onset methicillin-resistant Staphylococcus aureus bacteremia in Northern Australia. Int J Infect Dis 8: 275-283, 2004.

10. Haque NZ, Davis SL, Manierski CL, et al. Infective endocarditis caused by USA300 methicillin-resistant Staphylococcus aureus (MRSA). Int J Antimicrob Agents 30: 72-77, 2007. 
11. Miller M, Cespedes C, Bhat M, Vavagiakis P, Klein RS, Lowy FD. Incidence and persistence of Staphylococcus aureus nasal colonization in a community sample of HIV-infected and uninfected drug users. Clin Infect Dis 45: 343-346, 2007.

12. Naimi TS, LeDell KH, Como-Sabetti $\mathrm{K}$, et al. Comparison of community- and health care-associated methicillin-resistant Staphylococcus aureus infection. JAMA 290: 2976-2984, 2003.

13. Vandenesch F, Naimi T, Enright MC, et al. Community-acquired methicillin-resistant Staphylococcus aureus carrying PantonValentine leukocidin genes: worldwide emergence. Emerg Infect Dis 9: 978-984, 2003.

14. Lu PL, Chin LC, Peng CF, et al. Risk factors and molecular analysis of community methicillin-resistant Staphylococcus aureus carriage. J Clin Microbiol 43: 132-139, 2005.

15. Chen CJ, Huang YC. Community-acquired methicillin-resistant Staphylococcus aureus in Taiwan. J Microbiol Immunol Infect 38: 376-382, 2005.

16. Chen CJ, Huang YC, Chiu CH, Su LH, Lin TY. Clinical features and genotyping analysis of community-acquired methicillinresistant Staphylococcus aureus infections in Taiwanese children.
Pediatr Infect Dis J 24: 40-45, 2005.

17. Boyle-Vavra S, Ereshefsky B, Wang CC, Daum RS. Successful multiresistant community-associated methicillin-resistant Staphylococcus aureus lineage from Taipei, Taiwan, that carries either the novel Staphylococcal chromosome cassette mec (SCCmec) type $\mathrm{V}_{\mathrm{T}}$ or SCCmec type IV. J Clin Microbiol 43: 4719-4730, 2005.

18. Huang YH, Tseng SP, Hu JM, Tsai JC, Hsueh PR, Teng LJ. Clonal spread of SCCmec type IV methicillin-resistant Staphylococcus aureus between community and hospital. Clin Microbiol Infect 13: 717-724, 2007.

19. Baddour LM, Wilson WR, Bayer AS, et al. Infective endocarditis: diagnosis, antimicrobial therapy, and management of complications: a statement for healthcare professionals from the Committee on Rheumatic Fever, Endocarditis, and Kawasaki Disease, Council on Cardiovascular Disease in the Young, and the Councils on Clinical Cardiology, Stroke, and Cardiovascular Surgery and Anesthesia, American Heart Association: endorsed by the Infectious Diseases Society of America. Circulation 111: e394-e434, 2005.

20. Hsueh PR, Liu CY, Luh KT. Current status of antimicrobial resistance in Taiwan. Emerg Infect Dis 8: 132-137, 2002.

(C) 2008 The Japanese Society of Internal Medicine http://www.naika.or.jp/imindex.html 